\title{
Courtship, vocalization, and tadpole description of Epipedobates flavopictus (Anura: Dendrobatidae) in southern Goiás, Brazil
}

\author{
Ronan Caldeira Costa ${ }^{1}$, Kátia Gomes Facure ${ }^{1}$ \& Ariovaldo Antonio Giaretta ${ }^{1}$
}

Biota Neotropica v6 (n1) - http://www.biotaneotropica.org.br/v6n1/pt/abstract?article+bn00506012006

\author{
Date Received 06/13/2005 \\ Revised 10/07/2005 \\ Accepted 01/01/2006
}
${ }^{1}$ Laboratório de Taxonomia, Ecologia Comportamental e Sistemática de Anuros Neotropicais. Instituto de Biologia. Universidade Federal de Uberlândia. CEP: 38400-902. Uberlândia - Minas Gerais. Brasil. e-mail: ronancal@yahoo.com.br

\begin{abstract}
Epipedobates flavopictus is a diurnal, aposematic dendrobatid with a wide distribution in seasonal wet tropical regions of Brazil. We describe the daily period of vocalization, advertisement call, courtship behavior, and tadpole of E. flavopictus from a previously unknown population in southern Goiás and compare theses features with that of other populations. Studies were carried out in November (2004) and February (2005). We counted the number of calling males and duration of calling bouts in the morning and evening periods. The advertisement call was recorded with a digital recorder. Tadpole description was based on specimens collected in pools. Males called from well-illuminated sites such as rocky fields, rain channels, and borders of riverine forests. In November, males vocalized daily during two distinct periods, between 04:30 h and 10:00 h and between 16:30 h and 20:00 h. Morning temperature varied between $20-23^{\circ} \mathrm{C}$ and humidity from $79-89 \%$; during evening varied between $24-27^{\circ} \mathrm{C}$ and $54-82 \%$. In the middle of the day, temperature reached $36^{\circ} \mathrm{C}$ and humidity $40 \%$. During the morning, call activity was almost uninterrupted, in the evening calling bouts lasted around 9 min. In February, even with the occurrence of rainfall and temperatures similar to that of November no frog vocalized. The advertisement call is composed by a single note with 7-8 pulses with frequency ascending slightly from 3.20 to $4.05 \mathrm{kHz}$. Note duration was $144 \mathrm{~ms}$, and between note intervals is $292 \mathrm{~ms}$. Notes are given at a rate of 139 per minute. Upon observing the female, the male began to emit courtship call. The female approached the male and touched him laterally with her snout. The male moved forward and raised his hindquarters by stretching his hind legs. While leading the female, the male continued to give courtship and advertisement calls. The male clasped the female in axillary amplexus, and the pair entered a hole in a bank. The female deposited eggs on the surface of the soil, spreading them in groups. The egg clutches had eggs in at least two developmental stages, recently deposited and with embryos. Tadpoles were found in small, shallow rocky pools along a permanent stream, in well-illuminated sites at the forest border. The tadpole had the dorsal fin arched, not extending onto body. E. flavopictus appears to be unique among dendrobatids by using open areas subject to high temperatures and low humidity. Reproductive activity of the species ends before the end of the rainy season, possibly to avoid loss of tadpoles during months with unpredictable rainfall. The studied call had more notes and shorter between-call intervals than those described from other populations. The free-living tadpoles we describe differ from those of other populations by having the dorsal fin reduced.
\end{abstract}

Key words: populational variation, Brazilian Cerrado, habitat, pattern of activity, behavior, reproduction, advertisement call 


\section{Resumo}

Epipedobates flavopictus é um dendrobatídeo diurno, aposemático que tem ampla distribuição em regiões tropicais do Brasil. Descrevemos o período diário de atividade de canto, canto de anúncio, comportamento de corte e girino de E. flavopictus de uma população previamente desconhecida do sul de Goiás e comparamos essas características às de outras populações. O estudo foi realizado em novembro de 2004 e fevereiro de 2005. Comparamos o número de machos em atividade de canto e a duração dos períodos de canto da manhã e da tarde. O canto foi gravado com aparelho digital. A descrição dos girinos foi feita com base em espécimes coletados em poças. Os machos vocalizavam em sítios bem iluminados tais como ambientes rupestres e borda de matas ribeirinhas. Em novembro, os machos vocalizavam diariamente em dois períodos diferentes do dia; entre 04:30 h e 10:00 h e entre 16:30 h e 20:00 h. Durante a manhã, a temperatura variou entre 20 e $23^{\circ} \mathrm{C}$ e a umidade entre 79 e $89 \%$; durante a tarde variou entre 24 e $27^{\circ} \mathrm{C}$ e 54 e $82 \%$. No meio do dia, a temperatura chegou a $36^{\circ} \mathrm{C}$ e a umidade a $40 \%$. Durante a manhã, a atividade de canto era quase ininterrupta, e a tarde os períodos de canto duravam cerca de 9 min. Em fevereiro, apesar da ocorrência de chuvas e temperatura/umidade similares as de novembro, não houve atividade de canto. O canto de anúncio é composto por uma única nota com 7-8 pulsos, com freqüência ascendente de 3,20 a 4,05 kHz. A duração da nota é de 144 ms com intervalos de 292 ms. As notas são emitidas a uma taxa de 139 notas por minuto. Uma vez visualizada a fêmea, o macho começa a emitir canto de corte. A fêmea se aproxima do macho e o toca na lateral do corpo com o focinho. $\mathrm{O}$ macho se move pra frente e levanta o seu quarto traseiro esticando suas pernas. Enquanto conduzindo a fêmea, o macho continuava a emitir cantos de corte e de anuncio. O macho amplexou a fêmea axilarmente, e o par entrou num buraco no barranco. A fêmea depositou os ovos na superfície do solo, espalhando-os em grupos. Uma desova examinada tinha ovos em dois estágios diferentes de desenvolvimento: recém depositados e com embriões. Os girinos foram encontrados em pequenas poças rasas em rochas ao longo de um riacho permanente, em sítios bem iluminados na borda da floresta. Os girinos tinham a nadadeira dorsal arqueada, a qual não se estendia para o corpo. Aparentemente, E. flavopictus é o único entre os dendrobatídeos por usar áreas abertas sujeitas a altas temperaturas e baixas umidades. A atividade reprodutiva da espécie termina antes do fim da estação chuvosa, possivelmente para evitar perda de girinos durante meses com chuvas imprevisíveis. O canto estudado tinha mais notas e intervalos de cantos mais curtos que aqueles descritos de outras populações. O girino de vida livre que descrevemos difere do de outras populações por ter a nadadeira dorsal reduzida.

Palavras-chave: variação populacional, Cerrado brasileiro, habitat, padrão de atividade, comportamento, reprodução, canto de anúncio. 


\section{Introduction}

Epipedobates flavopictus A. Lutz, 1925 is a diurnal, aposematic (black, orange, and red) dendrobatid with a wide distribution in seasonal wet tropical regions in the Brazilian states of Minas Gerais, Goiás, Tocantins, northern Pará and northeastern Maranhão (Haddad \& Martins 1994). Some interpopulational variation in adult size and color has been recognized (Haddad \& Martins 1994). Haddad et al. (1988) and Haddad \& Martins (1994) described the call and the tadpole, and Toledo et al. (2004) described egg clutches and parental care in populations from Minas Gerais. In spite of these previous studies, some aspects of the behavior of $E$. flavopictus remain unknown, and interpopulational differences in morphology and call parameters are only partly documented. In the present study, we describe the daily period of vocalization, the advertisement call, courtship behavior, and tadpole of E. flavopictus from a previously unknown population in southern Goiás.

\section{Material and Methods}

\section{Study Site and Procedures}

This work was conducted during five days in November (2004) and in three days in February (2005) at Parque Estadual da Serra de Caldas Novas (PESCAN) (17²6’8.7" S and 48³9' 39" W; ca. 800 m altitude), southern Goiás, Brazil. The PESCAN encompasses an area of 12500 ha of Cerrado Biome. The climate is AW type, according to Köppen classification, corresponding to rainy/hot humid tropical climate with rains concentrated in summer (Santos 2003). Water bodies include permanent forest streams, seasonal small ( $<5$ liters) pools along rocky streams, and rocky rain channels. Around the administration facilities there is a stone garden with shallow $(<20 \mathrm{~cm})$ cement-bottomed pools.

Epipedobates flavopictus (Figure 1) was relatively common at the study site. We preliminarily determined the daily pattern of vocal activity of males of $E$. flavopictus for a $24 \mathrm{~h}$ period by visiting reproductive sites. Subsequently, the number of calling males was quantified along three $50 \mathrm{~m}$ transects of similar vegetational aspect. Site I was a rocky field (Cerrado Rupestre) (Figure 2-A); sites II and III were two segments of a rain channel (ca. $300 \mathrm{~m}$ apart) (Figure 2-B). Each transect was walked in the morning (between 04:00 h and 10:00 h) and evening (between 16:00 h and 20:00 h). During sampling, air temperature and relative humidity were measured each hour with a thermo-hygrometer (Hanna Instruments HI 8564). To compare the number of calling males in the morning and evening periods, we used the Wilcoxon matched pairs test (Zar 1999), performed considering the maximal number of males in each period. While sampling transects (mornings and evenings), we measures the duration of calling bouts with a stopwatch; bouts were arbitrarily considered different from one another if more than one minute elapsed between them. To check for site fidelity, males were recognized by their individual pattern of dorsal yellow spots (see Figure 18, pg. 37 in Eterovich \& Sazima 2004). On February 26, 27, and 28, we visited the same transects and surrounding areas to determine the presence of calling males.

Calls of one male were recorded with a Boss 864 digital recorder coupled to a Sennheiser ME67 microphone (44000 Hz; 16 bit resolution). Sound analysis was performed with Sound Ruler software (Gridi-Papp 2003). Tadpoles were collected in pools along permanent streams where males where heard. The tadpoles were described base on specimens preserved in 5\% formalin immediately after collection. Nomenclature for tadpole anatomy follows Altig \& McDiarmid (1999). A sample of tadpoles was kept in laboratory until metamorphosis to confirm identification; those used for description were between stages 25 and 37 (Gosner 1960). Measurements were taken with a caliper to the nearest $0.1 \mathrm{~mm}$.

Voucher specimens are housed at the frog collection of the Museu de Biodiversidade do Cerrado, at the Universidade Federal de Uberlândia. Adult AAG-UFU 2526; newly metamorphosed AAG-UFU 3157; tadpoles AAG-UFU 3151 (a lot with six tadopes).

\section{Results}

Males called from well-illuminated sites such as rocky fields, rain channels, borders of riverine forests, and at the rocky garden. In November, males vocalized daily during two distinct periods, between 04:30 h and 10:00 $\mathrm{h}$ and between 16:30 $\mathrm{h}$ and 20:00 h. During the morning, temperature varied from $20^{\circ} \mathrm{C}$ to $23^{\circ} \mathrm{C}$ and humidity from $79 \%$ to $89 \%$; in the evening, temperature ranged from $24^{\circ} \mathrm{C}$ to $27^{\circ} \mathrm{C}$ and from $54 \%$ to $82 \%$. In the middle of the day, when no male called (12:00 h to 15:00 h), temperature reached $36^{\circ} \mathrm{C}$ and humidity $40 \%$.

In the transects, the number of males calling during the morning (Median = 5) were not different from that calling during the evening (Median = 2) (Wilcoxon $\mathrm{Z}=-1.6$; $\mathrm{p}=$ 0.11). During the morning, call activity was almost uninterrupted, with bouts lasting as long as $60 \mathrm{~min}$ and the interval between bouts were short (ca. $1 \mathrm{~min}$ ). In the evening calls bouts lasted about 9 min (Mean = $503 \mathrm{~s} ; \mathrm{SD}=254 ; \mathrm{N}=5$ males); with intervals between bouts ranging from 10 to 20 min. In hot (Mean $=25{ }^{\circ} \mathrm{C}$; $\mathrm{SD}=0.8 ; \mathrm{N}=3$ days) rainy (humidity 92\%) days of February no male vocalized or was saw along transects.

The advertisement call of one male was composed by a single note whit 7-8 pulses (Figure 3) that ascended slightly from 3.20 to $4.05 \mathrm{kHz}$. Note duration was $144 \mathrm{~ms}$ (SD $=2.8, \mathrm{~N}=5$ ), and between note intervals were $292 \mathrm{~ms}(\mathrm{SD}=$ $5.61, \mathrm{~N}=5$ ). Notes were given at a rate of 139 per minute. 
One complete courtship sequence that culminated in egg deposition and two partial events were observed at the rain channel (Site II), all during the morning. In the complete sequence, the female approached a calling male. Upon observing the female, the male began to emit a low, peeping courtship call (not recorded). The female approached the male and touched him laterally with her snout. The male moved forward and raised his hindquarters by stretching his hind legs, thus revealing the orange coloration on his legs. The male continued to move, usually in about $30 \mathrm{~cm}$ increments, stopping to raise his cloacae. The female followed him, touching his flanks when he stopped, eventually completely turning around him. The male moved $2 \mathrm{~m}$ from the contact point while repeating this behavior; the female was never more than $20 \mathrm{~cm}$ apart from him. While leading the female, the male continued to give courtship and advertisement calls. The pair reached a small hole in the bank, where the male called from the entrance. The male clasped the female in axillary amplexus, and the pair entered the hole. After about $10 \mathrm{~min}$, the female began to deposit eggs on the surface of the soil, spreading the eggs in groups within a circle of ca. $10 \mathrm{~cm}$ diameter. It took 85 minutes from the beginning of the courtship to beginning of egg deposition.

Examination of the egg deposition site in the following afternoon revealed the presence of 20 eggs in at least two developmental stages, recently deposited and with developing embryos. Including the gelatinous capsules, the eggs with embryos measured between 4.4 and $4.7 \mathrm{~mm}$ in diameter $(\mathrm{N}=4)$. In the two other courtships observed the pairs also were near $(<1 \mathrm{~m})$ holes in the ground.

Seven tadpoles were found in two small, shallow (2 liters; $15 \mathrm{~mm}$ deep) rocky pools along a fast-moving permanent stream, in well-illuminated sites at the forest border. A male carrying tadpoles was seen near the pool in the stone garden. Syntopic frog species at the garden were Physalaemus cuvieri, Hyla sp. (gr. marmorata), Scinax fuscovarius, Leptodactylus syphax, and L. labyrinthicus.

Tadpole (Figure 4). Body ovoid in lateral and dorsal views. Nostril same distance from tip of snout as to eye; both nostril and eye positioned dorsolaterally. Spiracle sinistral, located equidistant at height and length of body, posterodorsally directed. Anal tube dextral, broad, without a free border. Dorsal fin arched, not extending onto body; tail tip rounded. Oral disc positioned ventrally, emarginated. Labial tooth row formula 2(2)/3(1); A-2 gap well defined and P-1 gap barely discernable; P-3 slightly shorter or same length as P-1 and P-2. Oral disc surrounded by papillae except for a broad anterior gap; papillae rounded. Papillae in a single row, although appearing alternated; some submarginal papillae laterally on disc and on posterior labium. Upper jaw sheath arc-shaped; lower jaw sheath U-shaped. Maximal observed length 29 mm (Gosner stage 41). Body 38\% the total length. In life, dorsal surface silver on a gray background; translucent tail with some black mottling; translucent belly, with some silver mottling. Snout-vent length 11.1 $\mathrm{mm}$ at metamorphosis $(\mathrm{N}=1)$.

\section{Discussion}

Among dendrobatids, choice of egg-laying sites is variable, with some species depositing eggs on the ground (Wells 1978, 1980a, 1980b, Roithmair 1994, Lima et al. 2002). Toledo et al. (2004) depicted a clutch of eggs of Epipedobates flavopictus in a mass; however, we found that eggs were spread in small groups. Dendrobatids are known to reproduce in primary or secondary forests (Rodriguez \& Duellman 1994), even those from the Cerrado (Haddad et al. 1988, Haddad \& Martins 1994). Epipedobates flavopictus appears to be unique among dendrobatids by using open areas subject to high temperatures and low humidity. Reproductive activity of Epipedobates flavopictus ends before February, prior the end of the rainy season, possibly to avoid loss of tadpoles during months with unpredictable rainfall.

Environmental variables such as humidity, temperature and photoperiod may determine anuran breeding period (Navas 1996, Navas \& Bevier 2001, Hatano et al. 2002). As in other diurnal frogs, the daily calling pattern of E. flavopictus may be related to moderate temperatures and higher humidity (Wells 1980a, 1980b, Navas 1996, Narvaes 1997, Heying 2001, Hatano et al. 2002); although we did not measure light intensity, it seems that this factor was of secondary importance, since vocal activity occurred during full-night hours. We predict that on rainy mid-summer days the call activity may occur throughout the day. The two-phase calling period of E. flavopictus is similar to that described for $E$. macedo (Rodriguez \& Myers 1993) and E. parvulus (Rodriguez \& Duellman 1994). As indicated by the larger time the males spent calling and the number of observed courtship events, E. flavopictus is more active during the morning period.

Males of several species of dendrobatids lead females to egg-laying sites (Rodriguez \& Duellman 1994, Caldwell \& De Oliveira 1999, Lima et al. 2002); we observed this behavior in E. flavopictus as well. Among dendrobatids, multiple clutches at the same site have been reported for $E$. flavopictus (Toledo et al. 2004; present study) and for Colostethus nidicola (Caldwell \& Lima, 2003). This association between the male and the egg laying site may be indicative of the existence of parental care in the egg phase in these species, as already recognized in other species of the family (Weygoldt 1987, Pröhl \& Hödl 1999). 
Good quality territories usually result in access to more females (Heying 2001) and in greater offspring survival (Pröhl \& Hödl 1999). Territoriality, as evidenced by site fidelity in E. flavopictus, is expected in those prolongedbreeding frogs, and egg deposition usually occurs in defended areas (Wells 1977).

Geographic variation in call parameters, color pattern, and size of adults and larvae are known for several anurans (Wilczynski et al. 1992, Aresco 1996, Gascon et al. 1998). The call of E. flavopictus from our study area had more notes and shorter intercall intervals than those described from populations from Minas Gerais (Haddad \& Martins 1994, Haddad et al. 1988). Haddad \& Martins (1994) described E. flavopictus tadpoles based on specimens collected from a male's back and Martins \& Sazima (1989) presented a photo of a late-staged tadpole. The free-living tadpoles we describe here differ from those of Haddad \& Martins (1994) by having the dorsal fin reduced (not extending onto the body), a shorter P-1 gap, and, apparently, more numerous oral papillae. The specimen depicted by Martins \& Sazima (1989) also showed an extended dorsal fin. A reduced dorsal fin is a feature of several Epipedobates species, including E. braccatus, E. pictus, and E. hahneli (Haddad \& Martins 1994, Rodriguez \& Duellman 1994).

\section{Acknowledgements}

J. Caldwell provided helpful comments on the draft. Ricardo I. Campos, Kelly C. Spena and Alexandre G. Franchim helped with the manuscript edition. Grants by CNPq (AAG) and CAPES (KGF).

\section{References}

ALTIG, R. \& McDIARID, R.W. 1999. Body plan: Development and morphology. 1999. In Tadpole. The biology of anuran larvae (R.W. McDiarmid \& R. Altig, eds.). The University of Chicago Press, Chicago, p.24-51.

ARESCO, M.J. 1996. Geographic variation in the morphology and lateral stripe of the green treefrog (Hyla cinerea) in the Southeastern United States. Am. Mid. Nat. 135:293-298.

CALDWELL, J.P. \& DE OLIVEIRA, V.R.L. 1999. Determinants of biparental care in the spotted poison frog, Dendrobates vanzolinii (Anura: Dendrobatidae). Copeia 1999:565-575.

CALDWELL, J.P. \& LIMA., A.P. 2003. A new Amazonian species of Colostethus (Anura: Dendrobatidae) with a nidicolous tadpoles. Herpetologica 59:219-234.

ETEROVICK, P.C. \& SAZIMA, I. 2004. Anfíbios da Serra do Cipó - Minas Gerais - Brasil. Amphibians from the Serra do Cipó. PUC Minas, Belo Horizonte.
GASCON, C., LOUGHEED, S.C. \& BOGART, J.P. 1998. Patterns of genetic population differentiation in four species of Amazonian frogs: A test of the riverine barrier hypothesis. Biotropica 30(1):104-119.

GOSNER, K.L. 1960. A simplified table for staging anuran embryos and larvae with notes on identification. Herpetologica 16:183-190.

GRIDI-PAPP, M. 2003. Sound Ruler. V0904. http:// soundruler.sourceforge.net.

HADDAD, C.F.B., ANDRADE, G.V. \& CARDOSO, J.A. 1988. Anfíbios do Parque Nacional da Serra da Canastra, Estado de Minas Gerais. Brasil Florestal 64:9-20.

HADDAD, C.F.B. \& MARTINS, M. 1994. Four species of Brazilian poison frogs related to Epipedobates pictus (Dendrobatidae): taxonomy and natural history observations. Herpetologica 50:282-295.

HATANO, F.H., ROCHA, C.F.D. \& VAN SLUYS, M. 2002. Environmental factors affecting calling activity of a tropical diurnal frog (Hylodes phyllodes: Leptodactylidae). J. Herpetol. 36(2):314-318.

HEYING, H.E. 2001. Social and reproductive behaviour in the Madagascan poison frog, Mantella laevigata, with comparisons to the dendrobatids. Anim. Behav. 61:567-577.

LIMA, A.P., CALDWELL, J.P. \& BIAVATI, G.M. 2002. Territorial and reproductive behavior of an Amazonian dendrobatid frog, Colostethus caeruleodactylus. Copeia 2002:44-51.

MARTINS, M. \& SAZIMA, I. 1989. Dendrobatídeos: Cores e Venenos. Ciência Hoje 9(53):34-38.

NARVAES, P. 1997. Comportamento territorial e reprodutivo de uma nova espécie de Hylodes (Amphibia, Anura, Leptodactylidae) da Mata Atlântica do Sudeste do Brasil. Dissertação de mestrado, Universidade de São Paulo, São Paulo.

NAVAS, C.A. 1996. The effect of temperature on the vocal activity of tropical anurans: A comparison of high and low-elevation species. J. Herpetol. 30(4):488-497.

NAVAS, C.A. \& BEVIER, C.R. 2001. Thermal dependency of calling performance in the eurythermic frog Colostethus subpunctatus. Herpetologica 57(3):384-395.

PRÖHL, H. \& HÖDL, W. 1999. Parental investiment, potential reproductive rates, and mating system in the strawberry dart-poison frog, Dendrobates pumilio. Behav. Ecol. Sociob. 46:215-220.

RODRIGUEZ, L.O. \& DUELLMAN, W.E. 1994 Guide to the frogs of the Iquitos region, Amazonian Peru. Associoación de Ecología y Conservación, Amazon Center for Environmental Education and Research and Natural History Museum, The University of Kansas. Lawrence, Kansas. 
RODRIGUEZ, L. \& MYERS, C.W. 1993. A new poison frog Manu National Park, Southeastern Peru (Dendrobatidae, Epipedobates). Am. Mus. Nov. 3068:1-15.

ROITHMAIR, M.E. 1994. Field Studies on ReproductiveBehavior in two Dart-Poison Frog Species (Epipedobates femoralis, Epipedobates trivittatus) in Amazonian Peru. Herpetol. J. 4(3):77-85.

SANTOS, L.M. 2003. Florística e biologia reprodutiva de espécies de Melastomataceae no Parque Estadual da Serra de Caldas Novas e Parque Estadual de Pireneus, Goiás. Tese de Doutorado, Universidade Federal de Brasília, Brasília.

TOLEDO, L.F., GUIMARÃES, L.D.A., LIMA, L.P., BASTOS, R.P. \& HADDAD, C.F.B. 2004. Notes on courtship, egg-laying site, and defensive behavior of Epipedobates flavopictus (Anura, Dendrobatidae) from two mountain ranges of central and southeastern Brazil. Phyllomedusa 3(2):145-147.

WELLS, K.D. 1977. The social behavior of anuran amphibians. Anim. Behav. 25:666-693.

WELLS, K.D. 1978. Territoriality in the green frog (Rana clamitans): vocalizations and agonistic behaviour. Anim. Behav. 26:1051-1063.

WELLS, K.D. 1980a. Behavioral ecology and social organization of a dendrobatid frog (Colosthetus inguinalis). Behav. Ecol. Sociobiol. 6:199-209.

WELLS, K.D. 1980b. Social behavior and communication of a dendrobatid frog (Cololthetus trinitatis). Herpetologica 36(2):189-199.

WEYGOLDT, P. 1987. Evolution of parental care in dart poison frogs (Amphibia: Anura: Dendrobatidae). Z. Zool. Syst. Evolut.-frosch. 25:51-67.

WILCZYNSKI, W., KEDDYHECTOR, A.C. \& RYAN, M.J. 1992. Call Patterns and Basilar Papilla Tuning in Cricket Frogs .1. Differences among Populations and between Sexes. Brain. Behav. Evolut. 39(4):229-237.

ZAR, J. 1999. Biostatistical analysis. Prentice Hall, New Jersey.
Title: Courtship, vocalization, and tadpole description of Epipedobates flavopictus (Anura: Dendrobatidae) in southern Goiás, Brazil

Authors: Ronan Caldeira Costa, Kátia Gomes Facure \& Ariovaldo Antonio Giaretta

Biota Neotropica, Vol. 6 ( number 1): 2006

http://www.biotaneotropica.org.br/v6n1/pt/ abstract?article+bn00506012006

Date Received 06/13/2005 - Revised 10/07/2005

Accepted 01/01/2006

ISSN 1676-0611 


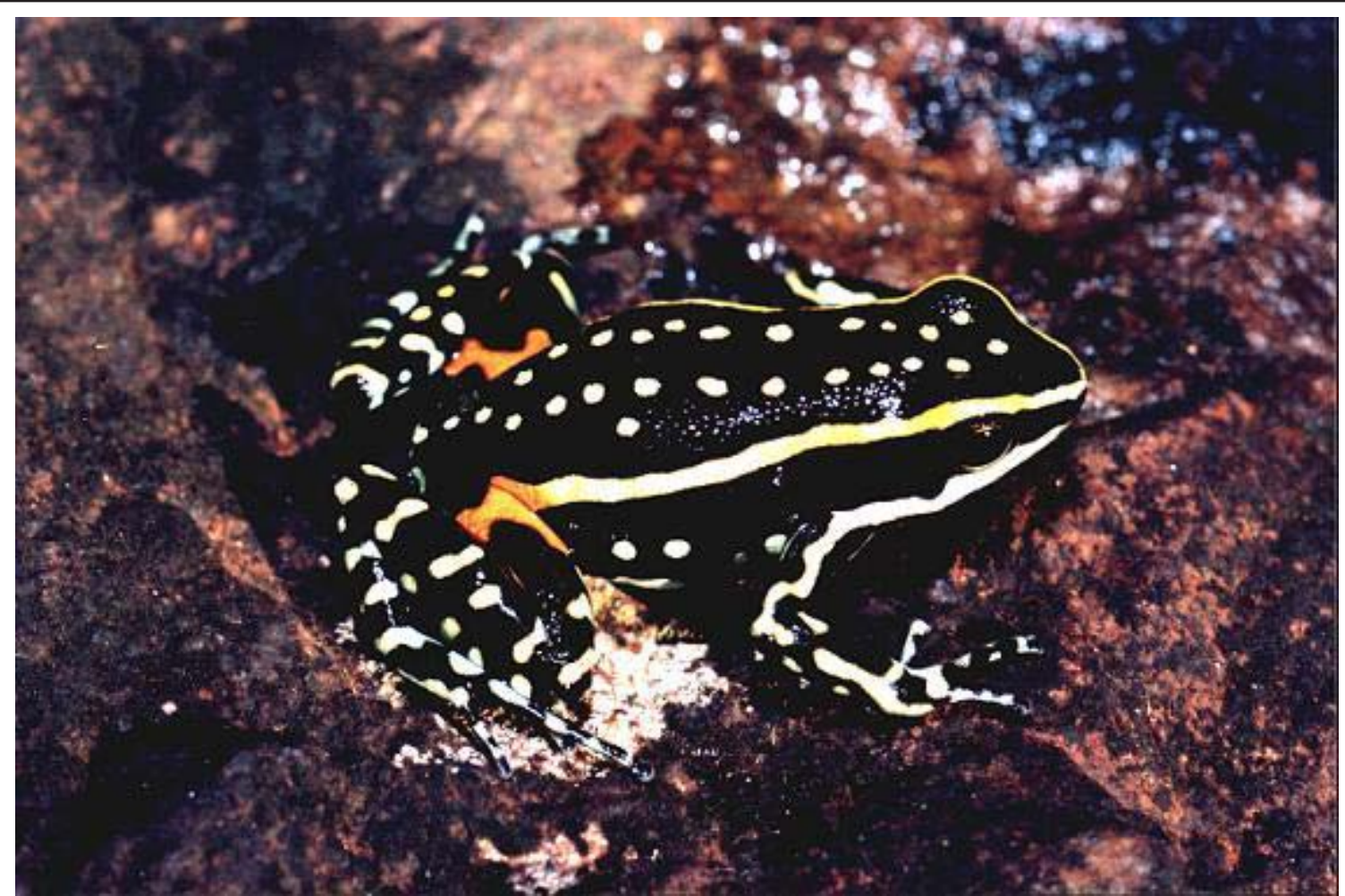

Figure 1. Adult male Epipedobates flavopictus. Municipality of Caldas Novas, Goiás, Brazil.

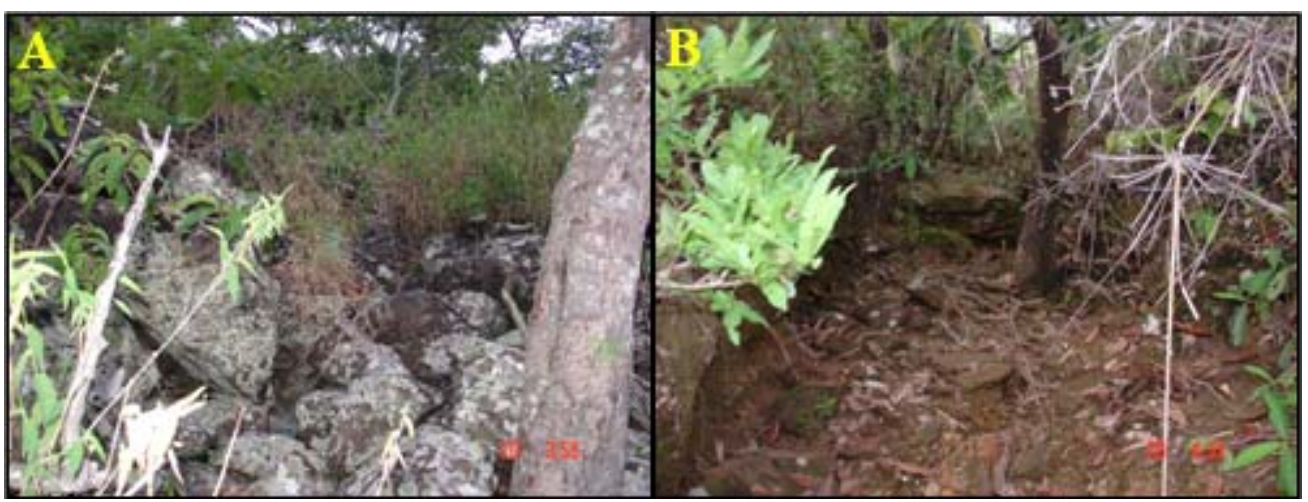

Figure 2. Calling sites of E. flavopictus. A - Rocky field (Cerrado Rupestre); B - Rain channel. Municipality of Caldas Novas, Goiás, Brazil (08/11/2004). 


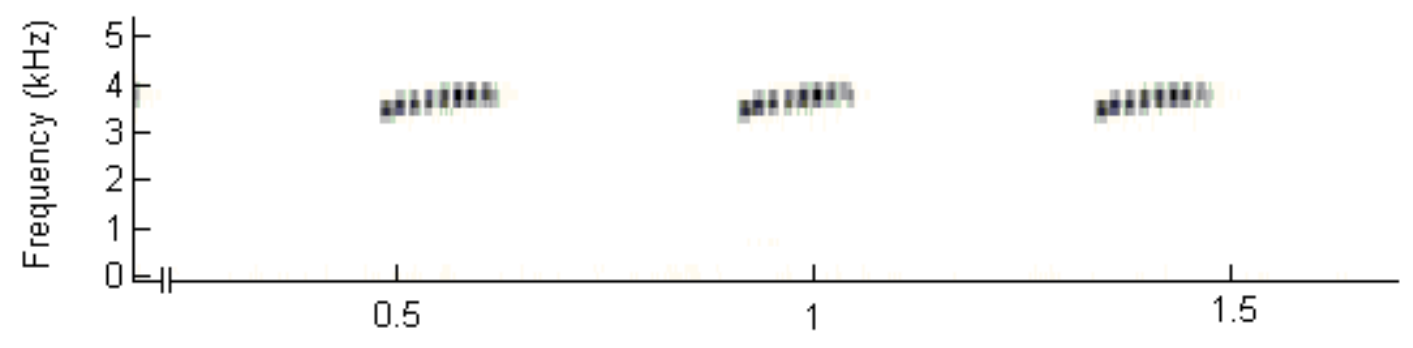

Time (s)

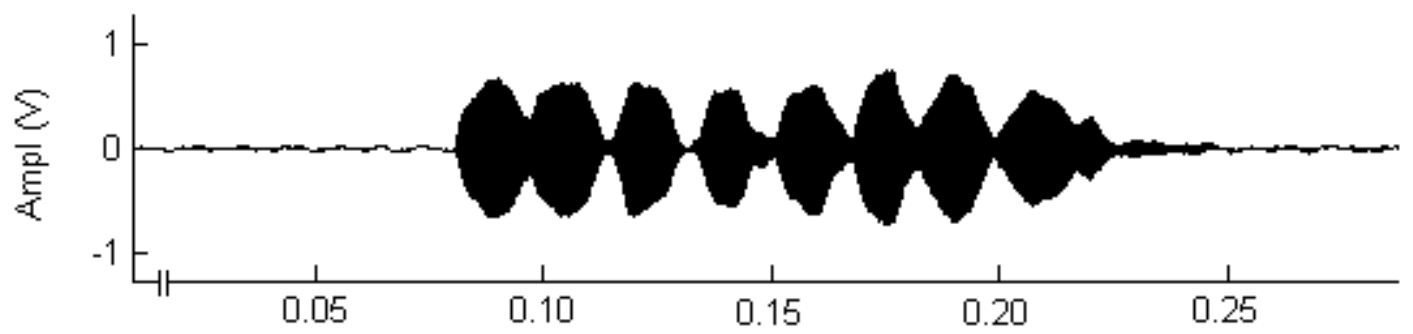

Time (s)

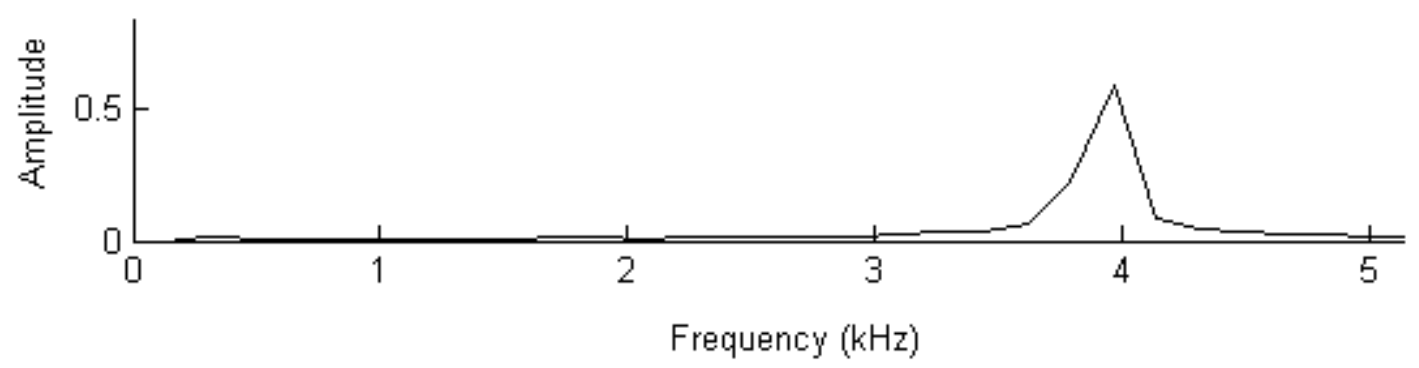

Figure 3. Advertisement call of Epipedobates flavopictus. Above-Spectrogram, Middle- Oscilogram of a single call. Below- Power Spectrum. Call recorded in November 2004. Air temperature, $23.5^{\circ} \mathrm{C}$, water temperature, $22.7^{\circ} \mathrm{C}$. Sound file EpipedflavopAAGd. Unvouchered record. Municipality of Caldas Novas, Goiás, Brazil. 

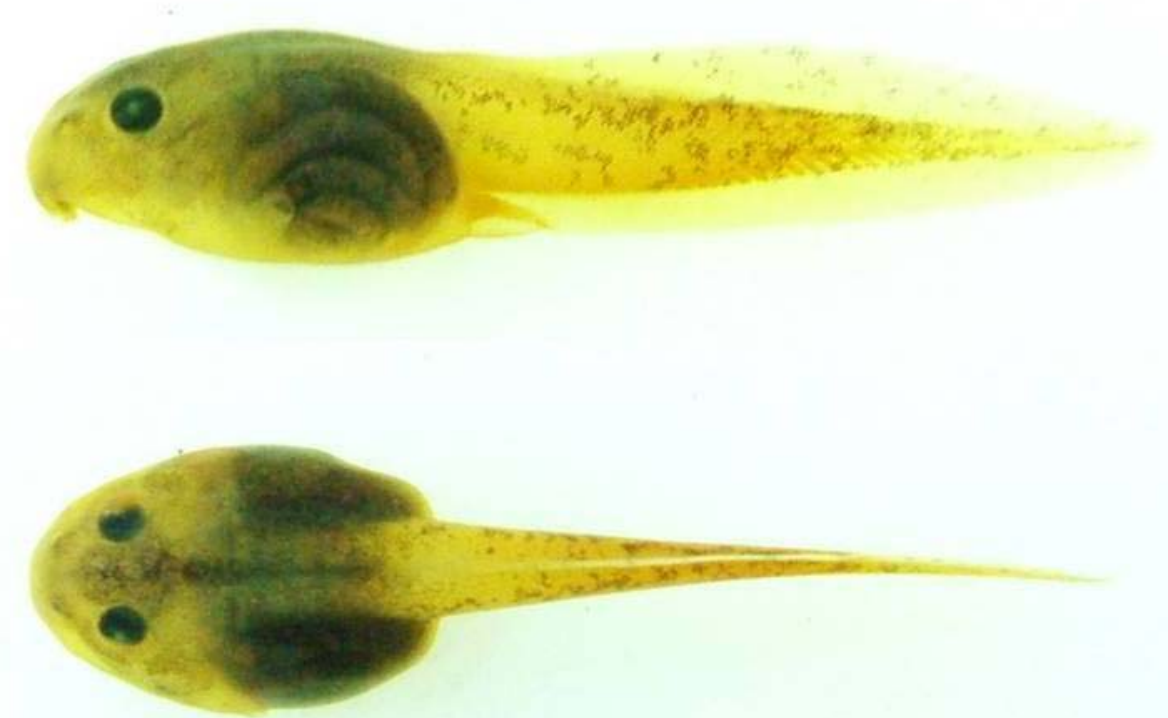

Figure 4. Left, dorsal, and ventral views of a tadpole of Epipedobates flavopictus. The left-sided picture shows that the dorsal fin does not extend onto the body. Gosner stage 27; $21.4 \mathrm{~mm}$ TL. Tadpole slightly stained with iodine. Municipality of Caldas, Novas, Goiás, Brazil. 